Article

\title{
The Finns Party: Euroscepticism, Euro Crisis, Populism and the Media
}

\author{
Juha Herkman \\ Department of Social Research, University of Helsinki, 00014 Helsinki, Finland; E-Mail: juha.herkman@helsinki.fi
}

Submitted: 25 October 2016 | Accepted: 28 November 2016 | Published: 27 March 2017

\begin{abstract}
In many European countries, populist right-wing parties have been most noticeable representatives of Euroscepticism. In Finland, the Finns Party (Perussuomalaiset) has been a constant promoter of organisational Euroscepticism through its leader, Timo Soini. The party broke through in Finland's 'big bang elections' of 2011, when the most debated issue was the European economic crisis, which was dominated by Eurosceptic Soini. Research concerning the relationship between the media, populism and Euroscepticism usually focus on national or European Parliament elections. This study analyses the media portrayal of the Eurosceptic Finns Party during times other than elections, focusing on the Finland's overall Euro crisis press coverage in 2010-2012. The analysis shows that the populist Finns Party has been a minor player in that coverage, which was dominated by the Euro positive political and economic elites. Differences between newspapers indicate that journalistic routines and political context direct media coverage toward particular framings, even when the media proclaims itself politically independent and neutral.
\end{abstract}

\section{Keywords}

Euro Crisis; Euroscepticism; Finland; frame analysis; media; populism

\section{Issue}

This article is part of a multidisciplinary issue of Media and Communication, edited by Epp Lauk (University of Jyväskylä, Finland) and Raul Reis (Emerson College, USA).

(C) 2017 by the author; licensee Cogitatio (Lisbon, Portugal). This article is licensed under a Creative Commons Attribution 4.0 International License (CC BY).

\section{Introduction}

Opposition to immigration and ethnic minorities can be described as the main themes unifying extreme right movements, however, populist right-wing parties have also promoted Euroscepticism (Caiani \& Conti, 2014; Mudde, 2007; Pirro, 2014). Hooghe, Marks and Wilson (2002) conclude this is because European integration combines several supposed threats-immigrants; external political and cultural influences; and European lawswhich populist right-wing parties perceive as undermining national sovereignty (pp. 976-977). Thus, the European Union (EU) and its institutions constitute a symbolic enemy to right-wing populist movements (Caiani \& Conti, 2014, pp. 186-188).

Taggart and Szczerbiak (2002, p. 31) noted that Eurosceptic parties are generally small and gain relatively low shares in national elections, making their political influence marginal. This might have been true at the beginning of the new millennium. However, since the expan- sion of the international financial crisis into a European debt and currency crisis in year 2008, Eurosceptic sentiment in many European countries has increased (Pew Research, 2013). The simultaneous increase in internal and external migrants in the EU has helped populist parties strengthen their political influence, allowing them into government in many countries.

Since the political and economic establishment has generally promoted the benefits of European integration, populist parties have been the most eager representatives of Euroscepticism in their domestic arenas. This is true for the Finns Party (Perussuomalaiset [PS], previously True Finns), a constant promoter of organisational Euroscepticism through its leader, Timo Soini. Even if there have been some exceptions depending on their government-opposition status of the moment, in general Finnish mainstream parties are favourable to European integration in comparison to their rank and file (Raunio, 2011, p. 204). Hence, PS's consistent Euroscepticism has been a defining image of the party. 
The Nordic party system has been identified as 'enduring' (Sundberg, 1999), but the Euro currency crisis has challenged it in Finland. The crisis is purported to be a main reason behind the 'big bang election' of 2011 (Arter, 2012), in which PS gained 19.1 percent of the vote, becoming the third largest party in the Finnish parliament (see Borg, 2012). According to the research, the European economic crisis became the most important topic in election campaign debates (Railo \& Välimäki, 2012a) and PS and Soini challenged the more established candidates, dominating agenda setting during the election campaigns (Pernaa, 2012, pp. 35-38; Railo \& Välimäki, 2012b, pp. 120-135).

However, the election campaign was a specific period in the relationship between Finland's political parties and the media. Similar specific periods have been found throughout Europe because research into Eurosceptics has concentrated on electoral campaigns (Schuck et al., 2011; Silke \& Maier, 2011; Strömbäck et al., 2011; Van Spanje \& De Vreese, 2014), and therefore PS studies have focused precisely on the 'big bang election' of 2011 (Arter, 2012; Borg, 2012; Rahkonen, 2011; Wiberg, 2011). Additionally, PS gained success in the 2015 parliamentary elections, gaining 17.7 percent of the vote and entering into government for the first time.

EU issues are especially prominent during election campaigns in countries with Eurosceptic parties (see Silke \& Maier, 2011), although media analysis of the Euro crisis coverage reveals the portrayal of the crisis is dominated by elites in favour of the Euro rather than Eurosceptics (Picard, 2015). To redress that focus on election periods, this study examines the role of PS's media coverage outside of electoral periods, namely the Euro crisis. Secondly, most studies indicate that media elites are generally more favourable to mainstream political parties upholding the political status quo, whereas the tabloid media is more 'populist' and promotes divisive politics (Leconte, 2010, p. 195; Mazzoleni, 2003, p. 8). Thus, it is worth exploring if there is difference between the quality and the tabloid media's portrayal of PS when referring to the Euro crisis.

The research questions (RQ) of the study are as follows:

RQ1. How has the Finns Party (PS) been portrayed in the Finnish press coverage of the Euro crisis?

RQ2. How does the portrayal differ compared to the coverage of the 'big bang elections' of 2011?

RQ3. What does the portrayal reveal about the relationship between the press and populist movements in general?

The data for the study has been collected as part of the large international research project that compared the press coverage of the Euro crisis in ten EU countries (Picard, 2015). The sample consists of 11 two-week periods between the years 2010 and 2012 and contains articles from the leading quality newspaper, the leading popular paper, the leading financial paper, and the most prominent regional paper in Northern Finland. The main study method is quantitative and qualitative frame analysis.

\section{Euroscepticism and the Media}

Even if Leconte (2010) has demonstrated in her book Understanding Euroscepticism that 'the perceptions of the EU are largely influenced by issues apparently unrelated to European integration, such as citizens' perception of national democracy, immigration, multiculturalism and so on' (pp. 246-247), Euroscepticism has most often been linked to doubts or distrust of the EU and its bodies and regulative power. The central position of the EU in Euroscepticism is because EU institutions and regulation are central to the debate over national sovereignty and European integration since the 1990s (Caiani \& Conti, 2014, pp. 186-187). Populist radical right-wing movements have adopted Euroscepticism to critique globalisation (Mudde, 2007).

It is possible to classify different levels or dimensions of Euroscepticism (e.g. Leconte, 2010, pp. 43-67). If we accept the definition of Euroscepticism as being the distrust of the EU, Euroscepticism can become organised by political parties or movements critical of the EU, or it may appear as general dissatisfaction among EU citizens. Euroscepticism can also be either strong and principledopposing EU membership or the union itself, or it can refer to weaker (soft) resistance on specific questions in which the interests of some member states conflict with EU regulation (Taggart \& Szczerbiak, 2002).

Euroscepticism has been strong, for example, in the UK. Taylor (2008) has crystallised a common EU theme found in British discussions: EU is far too expensive, 'Eurocratic' and self-serving, which prevents a reasonable agricultural policy; meddles with subjects it should not, such as domestic employment, health and security policies; and increases undesired immigration, resulting in social tensions in member states (pp. 34-35). In general, British Euroscepticism has mostly been focused on European Monetary Union (EMU) (Lubbers \& Scheepers, 2005 , p. 228) and on immigration (Luedtke, 2005). Similar arguments have been presented in other EU countries too (Caiani \& Conti, 2014), but in the UK attitudes against the EU led to Brexit in the July of 2016.

Therefore, Euroscepticism varies between countries (Leconte, 2010, p. 99). Whereas Euroscepticism has been strong in the UK both among citizens and policy-makers, France has traditionally been a 'Europhilic' country representing a positive attitude towards European integration. Euroscepticism has been strong in the Nordic countries, albeit weaker in Finland than in Sweden, Norway and Denmark-countries not in the EMU (Ekman, 2010, pp. 108-119). In addition to Eurosceptic and Europhile extremes, it is also possible to define 'critical Europeanist' countries such as the Netherlands in which the attitude 
towards European integration has been generally positive, although the attitude towards EU institutions is negative (Koopmans, Erbe, \& Meyer, 2010, pp. 91-92).

According to various surveys, Euroscepticism among EU citizens has increased during the last twenty years (Eurobarometer, 2015; Leconte, 2010, p. 161; Pew Research, 2013). Support for the EU was highest in the early 1990s, but by the beginning of the new millennium support had declined remarkably, for example, in the Netherlands, France and Italy, where the attitude towards European integration had been very positive (Caiani \& Conti, 2014, p. 184; Taylor, 2008, pp. 26-27). In many countries, distrust has confronted the attitudes of the establishment and ruling parties, which have generally promoted European integration. This, in turn, has created space for populist political parties that apply Eurosceptic rhetoric (Caiani \& Conti, 2014, p. 184; Ekman, 2010, p. 92).

Taggart and Szczerbiak (2002) claim that Eurosceptic parties will likely succeed in countries with multi-polar competition between the parties than in countries with bi-polar competition because, in multi-polar systems, peripheral parties can benefit from second-order issues, such as European integration, when differentiating themselves from more established parties (pp. 34-35). In addition, Paloheimo (2012) emphasises that populist parties have been especially successful in countries traditionally reliant on consensus in policy-making because the establishment is easily labelled a 'corrupt elite' by populists (p. 329).

Finnish EU policy has been based on consensus among established political parties, even if conflicts within parties on EU questions have appeared (Raunio, 2011, p. 198). This has opened a door through which the populist PS can act as a Eurosceptic voice, seducing voters. In addition to the structural transformation of industries and scandals concerning election campaign funding in Finland, Euroscepticism, containing distrust of and protest sentiment against established parties, has been shown to be one of the main reasons for PS's success in the 'big bang elections' of 2011 (e.g. Borg, 2012; Grönlund \& Westinen, 2012; Rahkonen, 2011).

Studies of the European Parliament (EP) elections of 2009 indicated that there is a correlation between the media portrayal of the EU and the election results: in countries with strong Eurosceptic parties, the negative portrayal of the EU has been more common than in other countries (Silke \& Maier, 2011; Van Spanje \& De Vreese, 2014). However, there were significant differences between the countries. In the 2009 EP election, the proEU frame dominated, for example, Italian, German and Finnish media coverage, whereas the anti-EU frame was strong in the Czech, Danish and UK media (Strömbäck et al., 2011, p. 171). In general, a negative tone on EU issues was more common than positive (Schuck et al., 2011, p. 177) - also in Finland and other Nordic countries (Schuck et al., 2011, p. 184). However, the EU was framed as beneficial in all other countries, except the UK, Austria and Czech Republic-the most prominent representatives of Euroscepticism (Schuck et al., 2011, pp. 186-187).

Thus, media coverage commonly portrays the EU as beneficial for the member states but regards EU institutions as reducing individual member state's democracy and sovereignty (Schuck et al., 2011, p. 193). This reflects discussions on the EU's 'democratic deficit', deriving from the disparity between Europe's institutional development and national public spheres as core arenas of political debate (Koopmans, 2007, p. 183; Leconte, 2010, p. 209; Schuck et al., 2011, p. 175). The European Commission has responded to the challenge with a strategic increase in transparency and public discussion (De Beus, 2010, p. 26; Heikkilä, 2007). However, as Hix (2008) reminds us, publicity strategies cannot bridge the gap between the European elites and European citizens if there are no real possibilities to challenge predominant policymaking at the EU level (p. 64).

The problem from the media's perspective has been that the mainstream European media have made the Euro elites their main source when discussing EU questions and issues, whereas the Eurosceptic views of those who have less political power have been marginalised (Koopmans, 2007). In Finland, journalists, on the whole, supported joining the EU more than the average citizen (Mörä, 1999). However, Finland has been an EU member state for over 20 years and the Euro crisis has seriously challenged the country's economy since 2012. Thus, the opinions and attitudes of journalists may have changed. In the coverage of the 2009 EP election the tone towards the EU was generally more positive in newer member states than in older ones, indicating that there is a "honeymoon period' (Schuck et al., 2011, p. 185).

Trenz (2007) has demonstrated that the quality press has, in general, promoted European integration and been EU positive. However, soft versions of Euroscepticism are quite common also in the quality press (Leconte, 2010, pp. 197, 218). Several studies indicate that the tabloid media adopts a Eurosceptic discourse more eagerly than the quality media and repeats the so-called 'Euro myths', especially in countries as the UK and Austria, which are known from their strong Eurosceptic sentiment (Leconte, 2010, pp. 195, 203-204). It is also worth acknowledging that Web-based communication and social media play significant roles in today's Eurosceptic mobilisation (Leconte, 2010, pp. 206-208). This is especially true with right-wing populist movements, whose supporters eagerly link the mainstream media to the liberal and corrupt elites and therefore strengthen their group identities via their own social media sites (Herkman, 2016).

\section{Materials and Methods}

The data here derive from a large comparative research project 'The Euro Crisis, Media Coverage, and Perceptions of Europe within the EU' organised by the Reuters Institute for the Study of Journalism at the University of 
Oxford (see Picard, 2015). The newspaper materials of the project were collected from ten EU countries: the UK, France, Germany, Spain, Italy, Greece, Netherlands, Belgium, Poland and Finland. The sample consists of articles that discuss the Euro crisis. The articles were gathered from four newspapers from each country during 11 twoweek periods during 2010 to 2012 . The selected newspapers included the leading liberal and conservative quality dailies, business or financial papers and tabloid or popular papers. The sampling periods were built around the 'key moments' of the crisis, including the EU summits in 2010, 2011 and 2012 as well as the Eurozone members' and the International Monetary Fund's agreement for the 100 billion euro loan for Greece on 2 May 2010 (Picard, 2015, pp. 269-273).

The sample included all journalistic articles such as news stories, editorials, interviews, feature stories, columns and commentaries published during the sample periods. However, letters to the editors were excluded from the sample. The coding book contained variables that considered the basic data of the articles, e.g., the size of the story, genre, author; the main topics and sources used in the articles; the main causes; responses; actors, winners and losers of the crisis-if there were any-as well as the geopolitical frame and portrayal of the EU institutions presented in the articles (Picard, 2015, pp. 273-293). In total, 10,492 articles were coded and analysed in the project.

In Finland, as in other Nordic countries, it is difficult to define newspapers according to the liberal/conservative axis since there is no such kind of political orientation in the Nordic newspaper field. Thus, Finnish dailies chosen for the sampling were the leading newspaper of the country Helsingin Sanomat, traditionally sympathetic towards European integration and Europhilic elites; the leading regional paper of northern Finland Kaleva, traditionally more critical towards EU and the Europhilic metropolitan elites; the leading business paper Kauppalehti; and the most popular tabloid I/ta-Sanomat. The Finnish sample contained 971 articles discussing the Euro crisis (see Harjuniemi \& Herkman, 2013, p. 15). The coding of the sample was carried out by two trained research assistants, whose inter-coder reliability was 0.78 according to the Holsti formula.

The coding book was supplemented for this study by variables exploring how much and in what way PS was portrayed in Euro crisis articles (Harjuniemi \& Herkman, 2013, p. 83). Only 61 Euro crisis articles, meaning six percent of the Finnish sample, mentioned PS. Two of the 61 articles did not actually discuss the expected topic and were thus excluded from the materials. Therefore, 59 articles remained from the larger sample of the Finnish Euro crisis coverage and were taken for qualitative frame analysis; 20 from Kaleva, 18 from Helsingin Sanomat, 15 from I/ta-Sanomat and only six from Kauppalehti.

The roots of frame analysis lay in Goffman's (1974) ideas on social experience, but since the 1980s the frame analysis has been applied by media studies and become one of the most popular methods of journalism studies (Borah, 2011). The definition of the 'frame' varies depending on the study, but usually it refers to the possible framings restricting or directing interpretations (Van Spanje \& De Vreese, 2014, p. 327). In journalism studies, framing refers to the processes in which the media emphasises some parts of reality and hides others by putting certain views to the fore of an article, thereby endorsing a particular interpretation (Entman, 1993, p. 53).

The frame analysis separates media frames from audience frames. The former is framing that the media carries out in portraying various topics, actors and phenomena, whereas the latter is the way audiences receive and interpret media texts (De Vreese, Jochen, \& Holli, 2001, p. 107). In political studies, the frame analysis is also used to comprehend the construction of political ideas and identities (e.g. Caiani \& Conti, 2014, p. 185). In this study, the focus is solely on media frames that are studied with reference to how the Finnish press framed PS in the Euro crisis articles. The main frames are found by sifting through sentences in which PS or its representatives are mentioned and by reflecting on how PS was presented in comparison with the context of the whole article.

\section{Finns Party and Coverage of the Euro Crisis}

According to election studies, the economic crisis in the EU region became the most popular topic of television debates and newspaper articles during the campaigns of Finnish elections in 2011, a debate led by the Eurosceptic PS (Railo \& Välimäki, 2012a, pp. 36, 53-57). However, debates on the Euro crisis appear to have had two phases. In the first phase, the media were highly critical of the EU institutions' and Finland's official policy during the crisis. However, after Portugal's government fell on 23 March 2011 because of the crisis, the Finnish media started to support Finland's official EU policy and sought a new economic consensus (Railo, 2012, p. 258-261). Thus, the significance of Euroscepticism faded during the campaigns once the crisis worsened.

The period of the 'big bang elections' and the collapse of Portugal's government are not included in the sample of this study. The sample contains the period before the spring of 2011, during which the EU Contract was changed on 16 December 2010, and the period after spring 2011, when the European Central Bank asked Italy for more austerity measures on 5 August 2011 (Picard, 2015, pp. 269-272). Therefore, the material here focuses on the coverage of the Euro crisis specifically from the point of view of the crisis not from the Finnish elections.

As mentioned, only six percent of the Euro crisis articles mentioned PS and not all of those articles promoted a Eurosceptic approach. Thus, it seems that PS gained only modest publicity at times other than elections. In contrast, the media coverage of the crisis was dominated by domestic and European political leaders, with economists often representing EU positive 'Euro elites' (Harjuniemi, Herkman, \& Ojala, 2015; Herkman \& 
Harjuniemi, 2015). The leader of PS, Timo Soini, was often quoted in Finnish Euro crisis articles, but less than the Prime Minister and the Minister of Finance or the EU's Financial Commissioner, Olli Rehn, and economists and other EU officials (Harjuniemi \& Herkman, 2013, pp. 21-29). Therefore, it is clear that PS did not define the Finnish media agenda during the Euro crisis.

However, since the 'big bang elections' made PS a legitimate debater on the Euro crisis, almost all the Euro crisis articles that mention PS were published after the 2011 elections. In fact, only six articles were published before the elections. Thus, PS's higher proportional share of media attention came after the election period. Furthermore, as the economic recession has become more topical since then, the continuing media spotlight on Euroscepticism has slightly strengthened (Harjuniemi \& Herkman, 2013, p. 19).

The Finnish press discussed the Euro crisis mostly as an economic issue to be covered by the business or financial sections of the papers (Harjuniemi \& Herkman, 2013 , p. 24). This also explains why PS was mentioned so infrequently and mostly in a negative light by the business paper Kauppalehti (see Table 1). Kauppalehti approached the crisis as an economic issue and mostly used economists and bankers for its sources. The other papers mentioned PS three times more often in their Euro crisis articles than Kauppalehti because they discussed the political dimensions of the crisis. The leading daily, Helsingin Sanomat, mentioned PS in six percent of its Euro crisis articles and generally gave more visibility to PS than Kauppalehti. Helsingin Sanomat also approached PS quite neutrally in its news journalism.

As a percentage of all Euro crisis stories, PS was most often mentioned in I/ta-Sanomat, in which 12 percent of all Euro crisis stories discussed the party or Soini. In addition, Ilta-Sanomat was most positive in its portrayal of PS, since only two of its articles clearly criticised the party. This indicates that I/ta-Sanomat adopted the most visible Eurosceptic approach. The paper also gave increased visibility to PS by publishing impressive images of Soini. Helsingin Sanomat and Kaleva published fewer images of him. In many ways, Kaleva was the antithesis of IItaSanomat in its portrayal of PS; even though Kaleva men- tioned PS quite frequently, the party was repeatedly discussed in a negative light and even downplayed.

Different assessments can be partly explained by the article types. In Kaleva and Kauppalehti PS was mentioned quite often in editorials and commentariesarticle types in which critical statements are commonwhereas in Helsingin Sanomat and in I/ta-Sanomat PS was more often discussed in news stories that emphasise the more objective and neutral tone of factual reporting. However, political and ideological grounds can also be found, especially for Kaleva's critical portrayal of PS.

Since PS was portrayed so infrequently in Finnish Euro crisis articles, it is not possible to make any statistically reliable conclusions about the subject. However, a few recurring frames was possible to identify from the data. The material found in 59 articles introduced ten frames in which the interpretations of PS were delimited by the media. Some of these frames were very specific concerning, for example, Soini's candidacy for the 2012 presidential elections. When these kinds of specialties and overlaps between the frames were eliminated, three main frames could be defined, namely: (1) PS as a representative of the opposition, (2) PS as a representative of populism, and (3) PS as a representative of Euroscepticism (see Table 2).

A single article might employ several frames, but usually one frame dominated the portrayal of PS. The most common primary frame was that of 'opposition'. The 'populism' frame was the second most popular, and 'Euroscepticism' came third. However, 'Euroscepticism' was evidently most common as a secondary frame. Thus, one can argue that PS was usually presented as a representative of opposition or populist politics, although these presentations were frequently accompanied by the Euroscepticism frame. The opposition frame was complemented by the Euroscepticism frame especially in news stories, whereas editorials and commentaries favoured a populist frame with a critical assessment of PS. Each frame will be next introduced in more detail.

Opposition Frame. This frame emphasized PS as a representative of domestic opposition politics. In opposition frame PS was seen typically as a contender or challenge to government rather than as a proponent of its own

Table 1. Finns Party (PS) in Euro crisis articles $(n=971)$.

\begin{tabular}{lcccc}
\hline Newspaper & $\begin{array}{l}\text { PS in articles (total } \\
\text { amount of articles) }\end{array}$ & $\begin{array}{l}\text { Share from all } \\
\text { articles (\%) }\end{array}$ & $\begin{array}{l}\text { Visibility of PS } \\
\text { in articles }\end{array}$ & $\begin{array}{l}\text { Assessment of PS } \\
\text { in articles }\end{array}$ \\
\hline $\begin{array}{l}\text { Kauppalehti } \\
\text { (business paper) }\end{array}$ & $6(309)$ & $2 \%$ & Minor & Negative \\
\hline $\begin{array}{l}\text { Helsingin Sanomat } \\
\text { (leading daily, capital area) }\end{array}$ & $18(312)$ & $6 \%$ & Modest & Neutral \\
\hline $\begin{array}{l}\text { Kaleva } \\
\text { (regional daily, Northern Finland) }\end{array}$ & $20(228)$ & $9 \%$ & Minor/modest & Negative \\
$\begin{array}{l}\text { Ilta-Sanomat } \\
\text { (popular paper) }\end{array}$ & $15(122)$ & $12 \%$ & Sizeable & Positive \\
\hline
\end{tabular}


agenda. The party was thus defined by what it is not (i.e. a government participant). In consensus democracies such as Finland government/opposition division is one of the most important dimensions structuring the party field and, therefore, it is not a surprise that this frame was most common and used by all newspapers included to the study, because PS was an opposition party during all sample periods of 2010-2012.

Opposition frame was most common in news stories published by dailies. Especially Helsingin Sanomat favoured this framing that was used also in such story headlines as 'Opposition accuses the government for increasing the charges of Finland' (3 August 2011) or 'Opposition scolded the Prime Minister Katainen' (3 July 2012). Opposition frame appeared several times in Helsingin Sanomat news stories as neutral mentions of PS (e.g. 8 May 2010; 3 August 2011).

However, quite often the opposition/government division was dramatized by using metaphors known from sports and conflict narratives (cf. Joris, Puustinen, Sobieraj, \& d'Haenens, 2015). This was common also in Helsingin Sanomat, in which the opposition was 'furious' with the schedule of parliamentary processing of collateral agreement with Spain (19 July 2012) or when the Prime Minister Katainen had to time after time 'deny allegations' (3 August 2011). Dramatization was even more typical in other papers, in which 'the government and the opposition clashed' (Kauppalehti 18 June 2012) or the leader of PS Soini 'attacked the government very hard' (Kaleva 9 November 2011). Usually attacker was the opposition and the government was defender (e.g. Ilta-Sanomat 7 October 2011).

Even if the opposition frame was most common in the news stories, it was also used in other story types highlighting the differences between the papers. Whereas popular paper IIta-Sanomat presented PS and its leader Soini quite often positively as the representatives of the opposition, regional paper Kaleva made usually completely different evaluations. This can be explained by the fact that even if Kaleva is announced to be politically independent the strong position of the Centre Party in the region Kaleva is distributed has implications to the alignments of the paper. In IIta-Sanomat PS was a snappy opposition party, whose leader's Eurosceptic blog writings were repeated almost as they were (28 November 2011), but in Kaleva PS was just a secondary opposition party 'accompanying Centre Party in its EU criticism' (3 August 2011). Thus, according to Kaleva the Centre Party was the primary opposition party (10 Au- gust 2011), and PS was often portrayed in negative or critical light (e.g. 21 July 2012).

Populism Frame. Populism as such is a slippery concept. Populism has been historically linked to very different left- and right-wing movements, totalitarian and democratic systems as well as nationalist and liberalist approaches (see Taggart, 2000). In many political cultures and languages the term 'populism' carries rather negative connotations (cf. Canovan, 2005, p. 75), even though the etymological background of the word, deriving from the Latin noun 'populus' meaning 'the people', gives it an emancipative or empowering signification (cf. Williams, 1988, p. 66). Pejorative meanings of 'empty talk' are common in accusations of someone being a 'populist', but other kinds of usages with more positive connotations of democracy have also been connected to populism (e.g. Canovan, 1999).

Mostly negative meanings of populism appeared in populism frame of PS. Surprisingly, the positive meanings of populism and PS representing 'the people' were also sometimes used in newspapers that generally were critical against the party. For example, in a commentary writing of Kauppalehti, PS was presented as fresh air in EU politics between the people and the elites (17 August 2011), and also dailies noted Soini as a defender of democracy when the Finnish government rushed the parliamentary decision of EU loan programme for Spain during parliament's recess period (Kaleva 19 July 2012; Helsingin Sanomat 19 July 2012).

However, positive approaches of populism frame were most common in IIta-Sanomat that quite often presented Eurosceptic PS as a representative of 'the real people' opposing Europhilic political and economic elites. Ilta-Sanomat, for example, published a web survey asking if the support Finland pays for Greece is too much or not (3 May 2010). It was not a surprise that 94 percent of over 50,000 respondents thought that the amount of money was too much. In addition to the survey results, Soini promoted his Eurosceptic views in the article. Positive framing of populism was used also in other articles of IIta-Sanomat presenting PS as a mediator of 'the people' and challenger of the Euro elites (e.g. 7 November 2011). Contradiction compared to Helsingin Sanomat was striking: the leading quality paper of the country almost avoided using the populism frame.

The reason why populism frame was used so rarely in Helsingin Sanomat derives from the most popular meanings of the term in Finnish language. The term is used often pejoratively, combining the meanings of populist

Table 2. Main frames of Finns Party (PS) in Euro crisis articles $(n=59)$.

\begin{tabular}{llcc}
\hline Frame & As a primary frame & As a secondary frame & Total \\
\hline Opposition frame & 24 & 5 & 29 \\
Populism frame & 16 & 7 & 23 \\
Euroscepticism frame & 10 & 24 & 34 \\
Total & 50 & 36 & 86 \\
\hline
\end{tabular}


rhetoric or style to ideological emptiness. To call someone a 'populist' has been a negative statement in Finnish political discourse. This kind of pejorative use of populism frame was popular in editorials and commentaries of Kaleva and Kauppalehti, in which PS was most often discussed as a troublemaker on the Finnish political field. Especially Kaleva seemed to accuse PS of 'populist' Euro policies in its editorials and commentaries (4 and $17 \mathrm{Au}$ gust 2011; 13 November 2011; 26 June 2012; 21 July 2012). Kauppalehti also promoted this kind of approach to PS (18 August 2011; 31 October 2011; 18 June 2012).

Also in the 'big bang election' media coverage especially editorials and commentaries presented PS as a protest channel through which the voters could project their disappointments. However, EU policy and antiimmigration strategies of PS were criticized in these articles as 'populist rhetoric' (Hatakka, 2012, pp. 297301), and some writers thought that PS might even threat the very functionality of Finnish political system (Hatakka, 2012, p. 317). In Euro crisis coverage these kinds of evaluations were common especially on editorials and commentaries published by Kaleva and Kauppalehti in 2010-2012.

Euroscepticism Frame. Euroscepticism frame goes naturally hand in hand with PS because, as mentioned earlier, the party has represented most consistently Eurosceptic approach in Finnish political field during the twenty-first century (Raunio, 2011). Therefore, in Euroscepticism frame media echoed the self-definitions of PS. Again, popular paper I/ta-Sanomat applied most commonly the positive approach to Euroscepticism and PSthe stance indicated by an opinion poll asking if joining to EMU had been a mistake or not (1 June 2012). According to the poll, only the supporters of PS thought that Finland should not have been joined the EMU. Soini was commenting the result in a story so that he was glad if PS was the one and only Eurosceptic party in Finland.

Euroscepticism as a primary frame was most popular in I/ta-Sanomat, which gave in all most positive and notable publicity to PS (cf. Harjuniemi \& Herkman, 2013, p. 59). Thus, PS and its leader Soini promoted in IltaSanomat directly their political agenda, which was not oppressed by opposition or populism frames. Soini argued in Ilta-Sanomat that he had been right all the time when warning about the support of the European banks (30 June 2012) or when the 'Europhilic government' had to explain away their EU policies (11 August 2011; 12 July 2012). The paper also quoted some other Eurosceptic commentators, such as economist Stefan Törnqvist from Ålandsbanken, who predicted the breakdown of the Eurozone.

In other newspapers the Euroscepticism frame was approached usually more neutrally than in I/ta-Sanomat. In Helsingin Sanomat news stories, for example, also other PS representatives than Soini, such as MP VesaMatti Saarakkala (28 October 2011) and MEP Sampo Terho (29 September 2011), criticised the government's EU policies. However, majority of Euroscepticism framings were secondary to the opposition frame that was the primary frame of PS in Helsingin Sanomat. Thus, first and foremost PS was presented as an opposition party which criticises the government about its EU policies.

The use of Euroscepticism frame commonly as a secondary frame in Helsingin Sanomat and in some news stories of Kaleva also can be explained partly by the sampling. The sample focusing solely on articles discussing Euro crisis emphasizes Euroscepticism as central topic of PS' opposition politics. In articles discussing PS outside the Euro crisis, other topics would have probably dominated. Critique of the campaign financing of the more established parties, but also immigration, were common issues in 'big bang election' coverages and promoted especially by PS and its leader Soini (Railo \& Välimäki, 2012a). These typical topics with a populist movement did not come out so much in media coverage of the Euro crisis.

\section{Discussion and Conclusions}

To answer RQ1, the role of the Eurosceptic PS turned out to be rather modest in determining media coverage of the 2010-2012 Euro crisis: only six percent of the Euro crisis articles mentioned PS or its representatives. In those articles, PS was primarily framed as a representative of the opposition or populism meaning a negative or neutral tone accompanied its portrayal. However, Euroscepticism was a common secondary frame and especially accompanied the opposition frame, indicating the significance of PS as a public representative of Finnish Euroscepticism.

The differences between the framings demonstrate differences between newspaper types. The business paper did not grant much attention to PS because it mostly discussed the Euro crisis as an economic issue, thus favouring economists and bankers as news sources (cf. Arrese \& Vara, 2015). In its rare articles that mentioned PS, the party was usually presented as a populist troublemaker. In daily newspapers, PS was given more visibility and discussed in a more neutral manner, even if the amount of articles was not very substantial and PS was portrayed negatively, especially in Kaleva.

The most significant difference between the newspaper types was that between the quality newspapers and the tabloid, which was the only newspaper to portray PS positively and adopt a Eurosceptic approach. The visibility given to PS was also remarkably greater in the tabloid than in other papers: PS was mentioned in 12 percent of all Euro crisis articles and often portrayed through flamboyant images of the party leader, Soini. Therefore, this study supports previous studies indicating that the tabloid media serves populist and Eurosceptic audiences more eagerly than quality newspapers (Jungar, 2010, pp. 215-216; Leconte, 2010, pp. 203-204; Mazzoleni, 2003, p. 8).

Compared to the media coverage of the big bang elections 2011 (RQ2), the attention given to PS appeared completely different: PS and Timo Soini were visible in election campaigns in defining the media agenda (Railo \& Välimäki, 
2012a), but the agenda setting power of the party turned out to be rather modest during the Euro crisis issue, although the visibility of PS seemed to increase slightly after the elections. Generally, the Euro crisis coverage was dominated by Euro-positive political leaders, the government and economists, whereas representatives of civil society were seldom mentioned or used as story sources (Harjuniemi \& Herkman, 2013, pp. 21-29). This accords with other studies of actors who 'inhabit the European public sphere' (Koopmans, 2007, pp. 203-206).

The sample period of this study ends in 2012. The consequences of the Euro crisis have since that struck Finland extremely hard. Thus, the archive of Helsingin Sanomat indicates that there might be more room for Euroscepticism in Finnish media coverage after 2013. Keynesian approaches and other alternatives to austerity have been discussed more often than during the sample period-when the Euro elite dominated debates. However, there is no evidence that PS would have gained more attention in those debates either. Since that PS has been profiled rather by its public criticism of immigration and by scandals that some of their representatives have faced.

Therefore, the study implies that the relationship between the populist movement and the media (RQ3), depends on many other variables than thematic issues such as Euroscepticism, which seems to be still quite marginal in Finnish mainstream media (cf. Taggart \& Szczerbiak, 2002). The most important factor in this relationship is the position of the populist party in a domestic political field. Thus, it is necessary to consider if the party is marginal or not in the political arena, whether it is in opposition or in government, in its insurgent phase or established-all these factors impact heavily on the overall media attention given to it (see Herkman, 2015). Therefore, it is probable that the dominant frames of opposition and populism have changed when PS became established and joined the government after the 2015 elections.

The media factor itself is another major variable defining the relationship between the populist party and the media. Obviously, the tabloid media adopts Eurosceptic sentiment more eagerly than quality media. Criticism for and against Euroscepticism is also more common in commentaries, editorials and columns than in news stories that tend to be more neutral. However, political affiliations between the media and domestic political parties appear to direct media coverage toward particular framings, even if the news media proclaims to be politically independent. For instance, the commitment to the Centre Party in Kaleva's editorials and commentaries indicates the strong impact of the party in the region in which the paper is published. Hence, the audience addressed by the particular media organisation may also greatly explain media frames regarding Euroscepticism and populism.

However, even more important media factor derives from journalistic routines. Several studies in Finland and elsewhere have indicated that the media attention em- phasizes leading politicians, such as key Ministers, explaining why PS was not a prominent agent in Euro crisis coverage during its opposition period (see Bos, Van der Brug, \& De Vreese, 2011; Suikkanen, Holma, \& Raittila, 2012). More specifically, as Bennett's (1990) 'indexing hypothesis' supposes, the mainstream media organizations usually adopt the hegemonic views of government debate, and challenging viewpoints are therefore introduced merely insomuch as they are emerged in these 'official circles' (p. 106). This is especially true in such countries as Finland whose media can even today be called 'politics friendly' (cf. Van Dalen, 2012).

The explicit difference between the Euro crisis coverages during the election campaign and times other also support the indexing hypothesis, which is intended to apply the everyday news accounts rather than coverage of such specific events as elections 'that may have a normative-ritual order of their own' (Bennett, 1990, p. 107). Thus, during the election campaign, the conflict frame enabled PS to challenge the established Europositive political elites that in other times dominated the everyday news stream. Therefore, it seems that to become a prominent point of view in the news media, Euroscepticism has to be promoted by established government politicians who either challenge the other decisionmaking elites by this view or adopt Euroscepticism as their hegemonic idea on European issues. For the moment, this does not seem to be a probable option in Finnish public discourse.

\section{Acknowledgements}

This work was supported by the Academy of Finland (under grant 259393) and 'The Euro Crisis, Media Coverage, and Perceptions of Europe within the EU' project, organized by the Reuters Institute for the Study of Journalism at the University of Oxford; the Finnish sub-study was funded by the Helsingin Sanomat Foundation.

\section{Conflict of Interests}

The author declares no conflict of interests.

\section{References}

Arrese, Á., \& Vara, A. (2015). Divergent perspectives? Financial newspapers and the general interest press. In R. Picard (Ed.), The Euro crisis in the media (pp. 149175). London: I. B. Tauris.

Arter, D. (2012). 'Big Bang' elections and party system change in Scandinavia: Farewell to the 'Enduring Party System'? Parliamentary Affairs, 65, 822-844.

Bennett, L. W. (1990). Toward a theory of press-state relations in the United States. Journal of Communication, 40(2), 103-125.

Borah, P. (2011). Conceptual issues in framing theory: A systemic examination of a decade's literature. Journal of Communication, 61(2), 246-263. 
Borg, S. (2012). Perussuomalaiset. In S. Borg (Ed.), Muutosvaalit 2011 (pp. 191-210). Helsinki: Oikeusministeriö.

Bos, L., Van der Brug, W., \& De Vreese, C. (2011). How the media shape perceptions of right-wing populist leaders. Political Communication, 28(2), 182-206.

Caiani, M., \& Conti, N. (2014). In the name of the People: The Euroscepticism of Italian radical right. Perspectives on European Politics and Society, 15(2), 183-197.

Canovan, M. (1999). Trust the People! Populism and the two faces of democracy. Political Studies, 47(1), 2-16.

Canovan, M. (2005). The People. Cambridge: Polity Press.

De Beus, J. (2010). The European Union and the public sphere. In R. Koopmans \& P. Statham (Eds.), The making of a European public sphere (pp. 13-33). Cambridge: Cambridge University Press.

De Vreese, C. H., Jochen, P., \& Holli, S. A. (2001). Framing politics at the launch of the Euro: A cross-national comparative study of frames in the news. Political Communication, 18(2), 107-122.

Ekman, J. (2010). Euroskepticism: Olika former av EUkritik. In J. Ekman \& J. Linde (Eds.), Politik, protest, populism-Deltagande på nya villkor (pp. 92-130). Malmö: Liber.

Entman, R. M. (1993). Framing: Toward clarification of a fractured paradigm. Journal of Communication, 43(4), 51-58.

Eurobarometer. (2015). Standard Eurobarometer 83. Retrieved from http://ec.europa.eu/public_opinion/ archives/eb/eb83/eb83 en.htm

Goffman, E. (1974). Frame analysis: An essay on the organization of experience. Cambridge, MA: Harvard University Press.

Grönlund, K., \& Westinen, J. (2012). Puoluevalinta. In S. Borg (Ed.), Muutosvaalit 2011 (pp. 156-190). Helsinki: Oikeusministeriö.

Harjuniemi, T., \& Herkman, J. (2013). Eurokriisi suomalaisissa sanomalehdissä 2010-2012. Helsinki: Helsingin yliopisto, sosiaalitieteiden laitos.

Harjuniemi, T., Herkman, J., \& Ojala, M. (2015). Eurokriisin politisoituminen suomalaisissa sanomalehdissä. Media \& Viestintä, 38(1), 1-22.

Hatakka, N. (2012). Perussuomalaisuuden kuva pääkirjoitus- ja kolumnijulkisuudessa. In V. Pernaa \& E. Railo (Eds.), Jytky. Eduskuntavaalien 2011 mediajulkisuus (pp. 294-322). Turku: Turun yliopisto/Kirja-Aurora.

Heikkilä, H. (2007). Beyond 'in so far as' questions: Contingent social imaginaries of the European public sphere. European Journal of Communication, 22(4), 427-441.

Herkman, J. (2016). Articulations of populism: The Nordic case. Cultural Studies. doi:10.1080/09502386. 2016.1232421

Herkman, J. (2015). The life cycle model and press coverage of Nordic populist parties. Journalism Studies. doi:10.1080/1461670X.2015.1066231
Herkman, J., \& Harjuniemi, T. (2015). Unity or heterogeneity: The promise of a European public sphere? In R. Picard (Ed.), The Euro crisis in the media (pp. 221235). London: I. B. Tauris.

Hix, S. (2008). What's wrong with the European Union and how to fix it. Cambridge: Polity Press.

Hooghe, L., Marks, G., \& Wilson, C. J. (2002). Does left/ right structure party positions on European integration? Comparative Political Studies, 38(8), 965-989.

Joris, W., Puustinen, L., Sobieraj, K., \& d'Haenens, L. (2015). The battle for the Euro: Metaphors and frames in the Euro crisis news. In R. Picard (Ed.), The Euro crisis in the media. Journalistic coverage of economic crisis and European institutions (pp. 125-145). London: L. B. Tauris.

Jungar, A.-C. (2010). Populismens återkomst: Hot eller löfte? In J. Ekman \& J. Linde (Eds.), Politik, protest, populism-Deltagande på nya villkor (pp. 202-224). Malmö: Liber.

Koopmans, R. (2007). Who inhabits the European public sphere? Winners and losers, supporters and opponents in Europeanised political debates. European Journal of Political Research, 46(2), 183-210.

Koopmans, R., Erbe, J., \& Meyer, M. F. (2010). The Europeanization of public spheres: Comparisons across issues, time, and countries. In R. Koopmans \& P. Statham (Eds.), The making of a European public sphere (pp. 63-96). Cambridge: Cambridge University Press.

Leconte, C. (2010). Understanding Euroscepticism. Basingstoke: Palgrave Macmillan.

Lubbers, M., \& Scheepers, P. (2005). Political versus instrumental Euroscepticism: Mapping Euroscepticism in European countries regions. European Union Politics, 6(2), 223-242.

Luedtke, A. (2005). European integration, public opinion and immigration policy. European Union Politics, 6(2), 83-112.

Mazzoleni, G. (2003). The media and the growth of neopopulism in contemporary democracies. In G. Mazzoleni, J. Stewart, \& B. Horsfield (Eds.), The media and neo-populism: A contemporary comparative analysis (pp. 1-20). Westport: Praeger.

Mörä, T. (1999). EU-journalismin anatomia. Mediasisältöjä muokanneet tekijät ennen kansanäänestystä 1994. Helsinki: Helsingin yliopisto.

Mudde, C. (2007). Populist radical right parties in Europe. Cambridge: Cambridge University Press.

Paloheimo, H. (2012). Populismi Puoluejärjestelmän vedenjakajana. In S. Borg (Ed.), Muutosvaalit 2011 (pp. 324-345). Helsinki: Oikeusministeriö.

Pernaa, V. (2012). Vaalikamppailu mediassa. In S. Borg (Ed.), Muutosvaalit 2011 (pp. 29-42). Helsinki: Oikeusministeriö.

Pew Research. (2013). The new sick man of Europe: The European Union. Retrieved from http://www.pew global.org/2013/05/13/the-new-sick-man-of-europe -the-european-union 
Picard, R. (Ed.). (2015). The Euro crisis in media: Journalistic coverage of economic crisis and European institutions. London: I. B. Tauris.

Pirro, A. (2014). Populist radical right parties in Central and Eastern Europe: The different context and issues of the prophets of the patria. Government \& Opposition, 49(4), 600-629.

Rahkonen, J. (2011). Perussuomalaisten ruumiinavaus. Onko työväen protestipuolueen kannatus saavuttanut vielä ylärajaansa? Yhteiskuntapolitiikka, 76(4), 425-435.

Railo, E. (2012). Euroopan unionin talouskriisin julkisuus-kritiikistä konsensukseen. In V. Pernaa \& E. Railo (Eds.), Jytky. Eduskuntavaalien 2011 mediajulkisuus (pp. 231-263). Turku: Turun yliopisto/KirjaAurora.

Railo, E., \& Välimäki, M. (2012a). Vaalikevään mediaagenda. In V. Pernaa \& E. Railo (Eds.), Jytky. Eduskuntavaalien 2011 mediajulkisuus (pp. 32-66). Turku: Turun yliopisto/Kirja-Aurora.

Railo, E., \& Välimäki, M. (2012b). Kamppailu julkisuuden hallinnasta. In V. Pernaa \& E. Railo (Eds.), Jytky. Eduskuntavaalien 2011 mediajulkisuus (pp. 100161). Turku: Turun yliopisto/Kirja-Aurora.

Raunio, T. (2011). Missä EU, siellä ongelma: Populistinen Eurooppa-vastaisuus Suomessa. In M. Wiberg (Ed.), Populismi. Kriitinen arvio (pp. 197-220). Helsinki: Edita.

Schuck, A., Azrout, R., Boomgaarden, H., Elenbaas, M., Van Spanje, J., Vliegenhart, R., \& De Vreese, C. (2011). Media visibility and framing of the European Parliamentary elections 2009. In M. Maier, J. Strömbäck, \& L. L. Kaid (Eds.), Political communication in European Parliamentary elections (pp. 175-196). Farnham: Ashgate.

Silke, A., \& Maier, M. (2011). National parties as politicizers of EU integration? Party campaign communication in the run-up to the 2009 European Parliament election. European Union Politics, 12(3), 431-453.

Strömbäck, J., Negrine, R., Hopmann, D. N., Maier, M., Jalali, C., Berganza, R., . . . \& Róka, J. (2011). The mediatization and framing of European Parliamentary election campaigns. In M. Maier, J. Strömbäck, \& L. L. Kaid (Eds.), Political communication in European Parliamentary elections (pp. 161-174). Farnham: Ashgate.

Suikkanen, R., Holma, A., \& Raittila, P. (2012). Muuttumaton uutinen? Suomalaisen uutismedian vuosiseuranta 2007-2012. Tampere: COMET.

Sundberg, J. (1999). The enduring Scandinavian party system. Scandinavian Political Studies, 22(3), 221-241.

Taggart, P. (2000). Populism. Buckingham: Open University Press.

Taggart, P., \& Szczerbiak, A. (2002). Europeanisation, Euroscepticism and party systems: Party-based Euroscepticism in the candidate states of Central and Eastern Europe. Perspectives on European Politics and Society, 3(1), 23-41.

Taylor, P. (2008). The end of European integration: Anti-Europeanism examined. Abingdon and Oxford: Routledge.

Trenz, H.-J. (2007). 'Quo vadis Europe?' Quality newspapers struggling for European unity. In J. E. Fossum \& P. Schlesinger (Eds.), The European Union and the public sphere: A communicative space in the making? (pp. 89-109). Abingdon: Routledge.

Van Dalen, A. (2012). Structural bias in cross-national perspective: How political systems and journalism cultures influence government dominance in the news. The International Journal of Press/Politics, 17(1), 32-55.

Van Spanje, J., \& De Vreese, C. (2014). Europhile media and Eurosceptic voting: Effects of news media coverage on Eurosceptic voting in the 2009 European Parliamentary elections. Political Communication, 31(2), 325-354.

Wiberg, M. (2011). Mitä populismi on? In M. Wiberg (Ed.), Populismi. Kriitinen arvio (pp. 11-21). Helsinki: Edita.

Williams, R. (1988). Keywords: A vocabulary of culture and society. London: Fontana.

\section{About the Author}

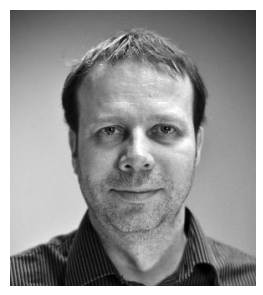

Juha Herkman (PhD) is an Academy Research Fellow in the Department of Social Research at the University of Helsinki, Finland. His current research project explores the relationship between populism and the media in the Nordic countries. Herkman has published several academic textbooks in Finnish, and articles in such journals as Cultural Studies, Media, Culture \& Society, Javnost-The Public, Nordicom Review, Journalism Studies and Convergence: The International Journal of Research into New Media Technologies. 